\author{
Nelia Titova \\ (D) https://orcid.org/0000-0003-0863-3307 \\ Uniwersytet Papieski Jana Pawła II w Krakowie
}

\title{
Człowiek w relacji do innych istot na Ziemi. Trendy współczesne
}

https://doi.org/10.15633/9788374389952.06

W niniejszym rozdziale zostaną poruszone kwestie związane z pojęciem solidarności w antropocentrycznym świecie - w kontekście etycznego stosunku do przyrody. Jako rozumne istoty Ziemi przedstawione będą delfiny i kaszaloty, które są uważane za istoty niebędące ludźmi. Niniejszy tekst porusza następujące tematy:

- podobieństwa i różnice między ludźmi i delfinami oraz kaszalotami jako rozumnymi istotami;

- charakterystyka delfinów oraz kaszalotów;

- etyczny charakter interakcji człowiek-delfin/kaszalot.

Badania naukowe nad inteligencją delfinów i ich zachowaniami społecznymi ujawniają, że delfiny posiadają wyrafinowane zdolności intelektualne i emocjonalne ${ }^{1}$. Naukowcy dochodzą do wniosku, że delfiny, nie będąc ludźmi, mają prawo do traktowania ich z pozycji moralnej osoby ludzkiej. Na koniec argumentują, że różne ludzkie praktyki związane z wykorzystywaniem delfinów i kaszalotów wyłącznie do celów rozrywkowych nie są etycznie do obronienia. Ostateczny cel tej pracy jest zatem praktyczny - ma on argumentować za położeniem kresu pewnym sposobom traktowania delfinów przez ludzi oraz za dążeniem do lepszego poznania i wchodzenia w interakcję z delfinami i kaszalotami na zasadach pewnego rodzaju partnerstwa.

Bezstronne i obiektywne badania dowodzą, że delfiny to „ktoś”, a nie „coś”, że w większości przypadków traktowanie delfinów przez ludzi jest

1 Por. D. L Herzing, T. I. White, Dolphins and the Question of Personhood, „Etica \& Animali. Special Issue” (1998) nr 9, s. 64-84, s. 65: „For millennia, and between anecdotal and scientific evidence, they have emerged as beings who are highly sophisticated - socially, intellectually and emotionally. However, dolphins remain especially vulnerable to harm from humans”. 
nieodpowiednie. Zdroworozsądkowe podejście do etyki zakłada, że jeśli istnieje uzasadniona możliwość, że działanie może kogoś skrzywdzić, to istnieje prewencyjny obowiązek unikania takiego działania. Oznacza to, że przynajmniej można mieć poważne wątpliwości co do etycznej akceptowalności pewnych praktyk w przemyśle rybnym i rozrywkowym. W związku z tym analiza danych musi skutkować wnioskiem, że jedynym etycznie właściwym sposobem działania jest zawieszenie takich praktyk jak łowienie delfinów i programy ich hodowli w niewoli. W przypadku delfinów fakt, że jest tyle badań naukowych na temat charakteru ich świadomości, daje mocne, niekontrowersyjne podstawy do sądu, że są to istoty rozumne. Nawet ludzie, którzy postrzegają świat w sposób całkowicie antropocentryczny, muszą przyznać, że dowody naukowe budzą wystarczająco dużo wątpliwości co do etycznej akceptowalności obecnych praktyk.

W tym rozdziale zostanie omówiona tylko kwestia delfinów i kaszalotów, ogólną kwestią „praw zwierząt” nie będziemy się zajmować. Strategia, która jest tutaj używana, nie powinna sugerować, że osobowość, świadomość oraz wyrafinowane zdolności poznawcze i afektywne są jedynymi - a nawet najlepszymi - filozoficznymi podstawami do wydawania osądów na temat etycznej dopuszczalności interakcji między ludźmi a istotami niebędącymi ludźmi. Tekst nie lobbuje za konkretną tradycją w filozofii moralnej lub w etyce. Stosowane jest bardzo podstawowe filozoficzne podejście do etyki, które skupia się na kwestii (potencjalnej) krzywdy i szkody oraz na prewencji. Nie są omawiane natomiast debaty o takich kwestiach filozoficznych jak na przykład natura jaźni, natura samoświadomości czy istnienie rozróżnienia między racjonalnymi a emocjonalnymi aspektami świadomości.

\section{Jakimi istotami są delfiny oraz kaszaloty?}

Ze względu na różne problemy ekologiczne, które uwidoczniły się w obecnych czasach, antropocentryczny model światopoglądu jest mocno kwestionowany ${ }^{2}$. Są to zauważalne skutki działalności człowieka w centrum tego świata ${ }^{3}$. Czy jest on najlepszym stworzeniem?

2 Por. R. R. Reeves, B. D. Smith, E. A. Crespo, G. Notarbartolo di Sciara, Conservation Action Plan for the World's Cetaceans IUCN/SSC Cetacean Specialist Group Dolphins, Whales and Porpoises, IUCN, Gland, Switzerland and Cambridge 2002-2010.

3 Por. Report of the Regional Workshop to Facilitate the Description of Ecologically or Biologically Significant Marine Areas in the Baltic Sea, Helsinki, 19-24 February 2018, Cbd/Ebsa/ Ws $/ 2018 / 1 / 4,27.02 .2018$. 
70 procent powierzchni Ziemi jest pokryte wodą ${ }^{4}$. Od ponad 50 milionów lat mieszkają w morzach delfiny i kaszaloty ${ }^{5}$. Ludzie zamieszkują tylko wyspy lądowe. W ciągu ostatniego miliona lat na lądzie pojawił się i szybko rozmnożył gatunek ludzki. W ciągu ostatnich dwóch wieków została stworzona cywilizacja zaawansowana technologicznie. Poziom rozwoju delfinów i ludzi znacznie przewyższa poziom rozwoju wszystkiego innego ${ }^{6}$. Te różne gatunki mają ze sobą wiele wspólnego. Oba mają największe i najlepiej zorganizowane mózgi na świecie. Zarówno jedne, jak i drugie są ssakami żyworodnymi. Oba gatunki oddychają tylko na powierzchni i nurkują, wstrzymując oddech. Temperatura ich ciał wynosi 36,6 stopni Celsjusza, co tłumaczy się pojemnością cieplną wody, z której w dużej mierze się składają. Posiadają indywidualny charakter i niepowtarzalne cechy ${ }^{7}$. Oba gatunki z łatwością przechodzą test lustra, który potwierdza obecność samoświadomości ${ }^{8}$. Delfiny przechodzą go zaraz po urodzeniu, a ludzie dopiero po osiągnięciu półtora roku. Oba gatunki posiadają najważniejszą cechę inteligencji: zdolność do postawy proaktywnej. Mogą nie kierować się okolicznościami zewnętrznymi, ale wewnętrznym kodeksem postępowania. Czasami nawet pokonują instynkt samozachowawczy w imię miłości, przyjaźni i współczucia oraz z innych powodów, które wykraczają poza osobisty poziom chwili9. Przy całej tej wspólnocie te dwa gatunki wybrały zasadniczo różne style życia

4 Secretariat of the Convention on Biological Diversity, 413 Rue St. Jacques, Suite 8oo, Montréal, Québec, H2Y 1N9 Canada, Tel. +1-514-288-2220 Fax: +1-514-288-6588, Email: secretariat@cbd.int, Web: www.cbd.int, (c) CBD Secretariat 2009. All Rights Reserved.

5 R. W. Boessenecker, M. Churchill, E. A. Buchholtz, B. L. Beatty, J. H. Geisler, Convergent Evolution of Swimming Adaptations in Modern Whales Revealed by a Large Macrophagous Dolphin from the Oligocene of South Carolina, July o9, 2020DOI:https://doi.org/10.1016/j.cub.2020.06.012, https:// www.cell.com/current-biology/fulltext/So960-9822(20)30828-9?utm_source=; (9.05.2021).

6 Por. Enchanting Dolphins: An Analysis of Human-Dolphin Encounters, w: Animals in person. Cultural perspectives on human-aniaml intimacies, red. V Servais, Oxford 2005, s. 211-229.

7 Por. The Human-Animal Boundary. Exploring the line in Philosophy and Fiction, red. N. Batra, M. Wenning, Leksington Books, Lanhan Boulder, New York 1978 .

8 D. Reiss, L. Marino, Mirror self-recognition in the bottlenose dolphin: A case of cognitive convergence, „PNAS” (2001) 98 (10) 5937-5942; https://doi.org/10.1073/pnas.101086398 (9.05.2021): „Collectively, these findings provide definitive evidence that the two dolphins in this study used the mirror (and other reflective surfaces) to investigate parts of their bodies that were marked. These findings, therefore, offer the first convincing evidence that a nonprimate species, the bottlenose dolphin, is capable of MSR”; „Life, awareness, positive and negative sensations. There is little question that dolphins meet the first three qualifications for personhood. Like all other animals, they are alive; they are aware of their surroundings; and they experience physical pleasure and pain".

9 Por. M. M. Samuelson, A. M. Ambert, C. D. Clark, M. Solangi, Description of a Unique Solitary Feeding Strategy Observed in Bottlenose Dolphins (Tursiops truncatus) in the Biloxi Marsh, Louisiana, „Animal Behavior and Cognition” 7 (2020) nr 4, DOI: https://doi.org/10.26451/abc.(7.04.03.2020) 
i wartości. W przypadku delfinów jest to bezpośredni kontakt z naturą. Dla ludzi jest to jej podbój i wykorzystanie. Kultura codzienna ludzi nastawiona jest głównie na tworzenie i konsumpcję przedmiotów materialnych. Kultura delfinów to bezpośrednia interakcja ze sobą i wszechświatem jako całością. Naturalnym narzędziem takiej interakcji dla delfinów nie są ręce czy urządzenia techniczne, ale mózg, serce i narządy zmysłów, które są w stanie nie tylko odbierać informacje, ale także je przekazywać. Umiejętności niezbędne do wykonywania tak różnych zadań leżą u podstaw najbardziej złożonych systemów społecznych, które oba gatunki posiadają, chociaż oczywiście systemy te są bardzo różne. Częścią takich systemów jest szkoła ${ }^{10}$. Szkoła delfinów zapewnia stabilną ciągłość przekazywania wiedzy. U ludzi podstawowa wiedza jest w dużej mierze podporządkowana obecnej umowie społecznej. I wskutek tego, zwłaszcza w krytycznych momentach w historii, fundamentalna wiedza o świecie jest albo utracona, albo zmieniona już w ciągu jednego pokolenia. Prawie każda aktywność delfinów obejmuje trzy główne elementy:

- zabawę jako twórczą symulację sytuacji;

- miłość jako źródło każdego działania;

- działanie jako wrażliwą interakcję z otaczającą przestrzenią.

Są one jedynymi stworzeniami na świecie, które nigdy w pełni nie śpią. I nawet w czasie odpoczynku nieustannie zachowują uwagę. Wszystkie te elementy są również obecne w życiu ludzi, ale są bardziej marginalne i ekskluzywne niż wiodące. Czas ludzi jest mniej więcej równo podzielony między trzema aktywnościami: snem, pracą i odpoczynkiem ${ }^{11}$. Praca to specyficzna aktywność ludzi w celu uzyskania materialnego zysku. Ta aktywność stoi na szczycie hierarchii ludzkich wartości. A będąc skrajnie oderwanym od naturalnych sfer życia, w naturalny sposób powoduje chroniczne zmęczenie u bardzo, bardzo wielu osób. To sprawia, że zwracają się do tak zwanego odpoczynku. To rozrywka, w głównej mierze wypełniona zewnętrznymi bodźcami sensorycznymi, generującymi swoisty stan zapomnienia, który pozwala zagłuszyć brak odpowiedzi na egzystencjalne pytania o sens, cel, naturę szczęścia i radości. Przy takim stylu życia naturalne jest, że większość ludzi czuje się odłączona, samotna, przygnębiona, zdezorientowana i niezdrowa.

10 Por. A. Winter, All about dolphinS! A multilingual educational manual, Produced by UNEP / CMS Convention on Migratory Species and TUI, United Nations Premises in Bonn 2007.

11 Por. K. Kwilecki, Rozważania o czasie wolnym. Wybrane zagadnienia, Wyd. Górnośląska Wyższa Szkoła Handlowa im. Wojciecha Korfantego, Katowice 2011. 
Rocznie odnotowuje się około 20 milionów prób samobójczych. Podobne stany, w szczególności depresja, występują również w życiu delfinów. Są one jednak spowodowane głównie przez takie zdarzenia jak utrata bliskich lub wolności ${ }^{12}$. Samobójstwa delfinów, także masowe, które w ostatnich latach stają się coraz częstsze, są konsekwencją czynników ludzkich, czyli antropogenicznych, takich jak nieznośne - przede wszystkim akustyczne - zanieczyszczenie ich środowiska.

Najważniejszym atrybutem rozumu jest wykorzystanie języka nie tylko jako środka komunikacji w obrębie własnego gatunku, ale jako narzędzia komunikacji z wszechświatem jako całością. Język ludzi zasadniczo składa się z kodów i symboli, które same w sobie są pozbawione życia i tylko zapośredniczone mogą w przybliżeniu przekazywać informacje ${ }^{13}$. Te kody i symbole nie są w żaden sposób związane ze stanem świadomości mówiącego. Pozwala to na przykład systematycznie kłamać. Język delfinów zakłada doskonałą zgodność mówiącego - psychologiczną i umysłową ${ }^{14}$. Jest nierozerwalnie związany ze swoim stanem emocjonalnym i prawdziwymi intencjami. Taki język jest przeznaczony do bezpośredniej interakcji z otoczeniem. Ludzie mieli takie elementy języka, ale teraz są one albo zagubione, albo zepchnięte w dziedzinę rozrywki, jaką jest muzyka, lub w obszar praktyk alternatywnych, takich jak modlitwa.

W tej chwili człowiek stał się czynnikiem decydującym o równowadze planetarnej. Dziś ludzkość wydaje większość swoich zasobów na tworzenie środków zniszczenia. Ponad połowa gatunków istot żywych została już bezpowrotnie zniszczona. Dziewięć dziesiątych powierzchni planety jest zanieczyszczone, a jej niezastąpione zasoby są prawie wyczerpane ${ }^{15}$. $\mathrm{Z}$ drugiej strony kaszaloty są najpotężniejszym czynnikiem stabilizującym planetę. Przede wszystkim dla dwóch najważniejszych zasobów: wody i powietrza. W wyniku ich życiowej aktywności pierwiastki chemiczne i związki niezbędne do tworzenia powietrza są wyprowadzane z głębin oceanów na powierzchnię. W ten sposób powstaje prawie dwie trzecie powietrza planety. Nazywa się to dużą pompą biologiczną. Jednocześnie pieśni wielorybów są najpotężniejszymi i harmonijnie zorganizowanymi wibracjami

12 Por. T. Frohoff, Lessons from Dolphins, Book Whales and Dolphins 2011.

13 Por. D. L. Herzing, T. I. White, Dolphins and the Question of Personhood, http://indefenseofdolphins.com/wp-content/uploads/2013/o7/dhtw1.pdf (9.05.2021).

14 Por. D. L. Herzing, T. I. White, Dolphins and the Question of Personhood..., dz. cyt.

15 Stan naszejplanety, Wypowiedź Sekretarza Generalnego ONZ na Uniwersytecie Columbia, 2 grudnia 2020 r., https://www.unic.un.org.pl/oionz/stan-naszej-planety/339o (9.05.2021). 
dźwiękowymi w żywej przyrodzie, działają leczniczo na zanieczyszczoną $\mathrm{i}$ „zdeformowaną” wodę, także na poziomie międzycząsteczkowym. Coroczne spotkanie tysięcy wielorybów w kilku punktach planety jest ważnym wydarzeniem $w$ równowadze planetarnej. Tak różne rezultaty działań delfinów i ludzi są w istocie naturalną konsekwencją przepaści dzielącej oba światopoglądy. Światopogląd ludzi w chwili obecnej nadal opiera się na założeniu samowystarczalności materii. Dlatego wszystkie związki przyczynowe są postrzegane przez ludzi wyłącznie na płaszczyźnie wyłącznie materialnej. Oczywiste jest, że takie zdolności delfinów jak umiejętność wykorzystania energii otaczającej przestrzeni czy możliwości terapeutyczne są uważane za niewytłumaczalne ${ }^{16}$. A dla społeczności naukowej są to na ogół tematy tabu. Nawet pływanie delfinów jest jedną z takich zagadek. Ponieważ przyjęte formuły „nie pozwalają” im pływać z taką prędkością przy dostępnych zasobach energetycznych. Delfiny są badane głównie przez biologów, zresztą w warunkach pozbawienia wolności, a nawet po ich śmierci, co oczywiście nic nie daje. Przy tak ogromnej przepaści praktycznie nie ma kontaktu między ludźmi a delfinami. Ludzie nie potrafią rozpoznać inteligencji u delfinów, ponieważ spowodowałoby to nieuniknioną rewizję ich własnych podstawowych wartości i stylu życia. Ludzkość woli, wydając na to kolosalne zasoby, na próżno poszukiwać w odległym kosmosie cywilizacji zaawansowanych technologicznie, podobnych do swojej, nie zauważając rozwiniętego umysłu, który znajduje się na wyciągnięcie ręki. Delfiny nie mają pytań o to, jak najlepiej skorzystać z możliwości konsumenckich, a jeśli mają, to inne - takie, które dla ludzkości jako gatunku pewnie nie istnieją. Niemniej jednak, na poziomie indywidualnym, naiwnym, zdarzają się kontakty między przedstawicielami obu gatunków. W żaden sposób nie definiują jednak one interakcji międzygatunkowych, ponieważ obecnie z delfinami pływa tylko kilka tysięcy ludzi na świecie. A jednak to nie wystarczy, chociaż dla każdego z nich ten kontakt ma charakter przeobrażający. Według jednej z definicji umysł to zdolność do używania sił świata bez niszczenia tego świata ${ }^{17}$. Wydawałoby się, że komunikat jest jasny. Ale jeden paradoks powstrzymuje od ostatecznej decyzji: cierpiąc z powodu nieznośnego zanieczyszczenia, floty wielorybniczej, uwięzienia, zmuszania ich do udziału w programach

16 Por. S. Casey, Voices in the Ocean: A Journey into the Wild and Haunting World of Dolphins, Anchor, London 2015.

17 Por. Пикник на обочине (Аркадий и Борис Стругацкие), Piknik przydrożny (Arkady i Borys Strugacki), 2006. 
rozrywkowych i eksperymentach wojskowych delfiny i kaszaloty nie reagują odwetem na ból. Nie mogą zabić człowieka. Dlaczego? Alexander i Nicole Gratovsky odpowiadają na to pytanie: „Po spędzeniu 5 tysięcy ziemskich godzin $z$ delfinami jesteśmy pewni, że odpowiedź brzmi: one widzą w ludziach to, czego ludzie nie widzą w sobie. Przypomina to stosunek osoby dojrzałej do nowonarodzonego dziecka, które nie wie, co robi. Nie ma powodu, aby się z nim komunikować. Jest tylko bezwarunkowa wartość jego życia, ponieważ jest w nim szansa"18. Delfiny mają na celu utrzymanie stabilności żyjącej planety, życia w ogóle. A ludzie mają na celu generowanie pomysłów, które zmieniają świat. Jakie będą te idee i jaki będzie następny świat, zależy od danego światopoglądu. Zwrócenie się ludzi do innej hierarchii wartości może nie tylko wyprowadzić ludzkość z cywilizacyjnego impasu, ale także dać jej możliwość uświadomienia sobie zawartego w niej kolosalnego potencjału do prawdziwego rozwoju.

\section{Proponowana deklaracja o prawach i wolności delfinów i wielorybów}

Grupa europejskich antropologów rosyjskiego pochodzenia Alexander i Nicole Gratovsky założyli Ambasadę Delfinów ${ }^{19}$ na Teneryfie. Uważają oni waleni za nosicieli najbardziej rozwiniętej -choć zorganizowanej inaczej niż ludzka - świadomości na planecie. W 2008 roku Gratovsky stworzył interdyscyplinarne centrum, które patrzy na współczesność nie z antropocentrycznej pozycji „zdobywcy przyrody” i jego „korony”, ale obserwuje planetę jako cały, żywy i inteligentny organizm. Naukowcy badają możliwości ustanowienia kontaktu między ludźmi a wielorybami. 18 listopada 2017 roku w Petersburgu odbyła się konferencja naukowo-praktyczna "Język i kultura delfinów” z udziałem czołowych badaczy wielorybów, takich jak Jim Darling, Hull Whitehead, Toni Frohoff i inni, co zaowocowało przyjęciem „Międzynarodowej Deklaracji o Ochronie Praw i Wolności Delfinów i Wielorybów” ${ }^{20}$, w której uznaje się walenie za „nie-ludzkie osoby, obdarzone samoświadomością rozumem i uczuciami ${ }^{21}$ " i proponuje się ustanowienie nowego typu ludzkiego stosunku do delfinów i wielorybów: bez przemocy, wyzysku

\footnotetext{
18 A. and N. Gratovsky, Nature of Wonders. Dolphin Embassy, 2019.

19 https://www.dolphinembassy.org/declaration (9.05.2021).

20 https://www.dolphinembassy.org/declaration (9.05.2021).

21 https://www.dolphinembassy.org/declaration (9.05.2021).
} 
i niewolnictwa. Deklarację podpisali wybitni naukowcy, osoby publiczne i pracownicy kultury $\mathrm{z}$ różnych krajów ${ }^{22}$.

W dniach 10-14 października 2019 roku w Delphi odbyło się Holistic Worldview Assembly, zorganizowane przez Gratovskich, które zgromadziło ponad 100 myślicieli, autorów przełomowych odkryć naukowych, idei i praktyk z całego świata. Inicjatorzy zgromadzenia sformułowali cel tego wydarzenia w następujący sposób: znalezienie sposobu przełamania impasu cywilizacji. Wśród uczestników byli: Ashok Kosla, współprzewodniczący Międzynarodowego Panelu Ekspertów Programu Środowiskowego ONZ, Barry Kerzin, osobisty lekarz Dalajlamy, Janusz Wiśniewski, pisarz, autor powieści „Samotność w sieci”, minister ds. kobiet oraz Child Development, działacz na rzecz praw zwierząt Maneka Gandhi, twórca teorii czwartego zbiorczego stanu wody Gerald Pollack, reżyser filmowy, scenarzysta i producent Georgy Ovashvili, szef Międzynarodowego Towarzystwa Badań Biosemiotycznych Kalevi Kull, szefowie największego międzynarodowego stowarzyszenia myślicieli - kluby rzymskie i budapeszteńskie i inni ${ }^{23}$. Zgromadzenie odbyło się „za zamkniętymi drzwiami”, celowo wykluczając obecność dziennikarzy i członków społeczeństwa. W sprawozdaniu ze zjazdu, opublikowanym w osobnej księdze ${ }^{24}$, stwierdza się, że konieczne i nieuniknione są pilne zmiany w dotychczasowym sposobie życia i hierarchii wartości ludzkości oraz nowe definicje fundamentalnych koncepcji egzystencjalnych, takich jak umysł, świadomość, życie i inne, sformułowane w formie współczesnych „maksym delfickich”, z których pierwsza brzmi: „Świadomość to umiejętność wyboru przyszłości”25.

Jak zostało nadmienione powyżej, zrównoważony rozwój biosfery Ziemi w znacznym stopniu zależy od czynników dostarczanych przez ekosystemy głębinowe. Bez biologicznych procesów w głębinach morskich (w których biorą udział delfiny i walenie) życie na Ziemi byłoby zagrożone. W tej chwili człowiek staje przed świadomym wyborem działań, decydujących o równowadze planetarnej. Niestety nie każda działalność ludzi służy dobru ziemskiej biosfery, w tym dobru innych istot. Być może kwestia solidarności z rozumnymi istotami niebędącymi ludźmi jest nie tylko racjonalnym wyzwaniem

22 https://www.dolphinembassy.org/declaration (9.05.2021).

23 https://www.dolphinembassy.org/declaration (9.05.2021).

24 A. and N. Gratovsky, Nature of Wonders. Dolphin Embassy, dz. cyt.

25 Warsztat Maxim, oficjalny film z Zgromadzenia NOW, («Мастерская Максим» официальное видео Ассамблеи NOW на YouTube), https://www.youtube.com/ (9.05.2021). 
dla człowieczeństwa w kontekście etycznym, ale także - dzięki pozaracjonalnym doświadczeniom z solidarności płynących - może prowadzić do harmonii, jaka powinna panować w świecie. Wartościami pozytywnymi postawy solidarnej mogą być nie tylko wartości etyczne, ale również konkretne, mierzalne wartości materialne dla całej ludzkości.

\section{Bibliografia}

Boessenecker R. W., Churchill M., Buchholtz E. A., Beatty B. L., Geisler J. H, Convergent Evolution of Swimming Adaptations in Modern Whales Revealed by a Large Macrophagous Dolphin from the Oligocene of South Carolina, July 09, 2020, DOI: https:// doi.org/10.1016/j.cub.2020.06.012.

Casey S., Voices in the Ocean: A Journey into the Wild and Haunting World of Dolphins, Anchor, 2015.

Enchanting Dolphins: An Analysis of Human-Dolphin Encounters, w: Animals in person. Cultural perspectives on human-aniaml intimacies, red. V Servais, Oxford 2005, s. 211-229

Frohoff T., Lessons from Dolphins, Book Whales and Dolphins 2011.

Gratovsky A., N., Nature of Wonders. Dolphin Embassy, 2019.

Herzing D. L., White T. I., Dolphins and the Question of Personhood, „Etica \& Animali. Special Issue" (1998) nr 9, s. 64-84.

https://www.dolphinembassy.org/declaration (9.05.2021).

Kwilecki K., Rozważania o czasie wolnym. Wybrane zagadnienia, Wyd. Górnośląska Wyższa Szkoła Handlowa im. Wojciecha Korfantego, Katowice 2011.

Reeves R. R., Smith B. D., Crespo E. A., Notarbartolo di Sciara G., Conservation Action Plan for the World's Cetaceans IUCN/SSC Cetacean Specialist Group Dolphins, Whales and Porpoises, IUCN, Gland, Switzerland and Cambridge 2002-2010.

Reiss D., Marino L., Mirror self-recognition in the bottlenose dolphin: A case of cognitive convergence, „PNAS” (2001) 98 (10) 5937-5942; https://doi.org/10.1073/ pnas.101086398 (9.05.2021).

Report of the Regional Workshop to Facilitate the Description of Ecologically or Biologically Significant Marine Areas in the Baltic Sea, Helsinki, 19-24 February 2018, Cbd/ $\mathrm{Ebsa} / \mathrm{Ws} / 2018 / 1 / 4,27.02 .2018$

Samuelson M. M., Ambert A. M., Clark C. D., Solangi M., Description of a Unique Solitary Feeding Strategy Observed in Bottlenose Dolphins (Tursiops truncatus) in the Biloxi Marsh, Louisiana, „Animal Behavior and Cognition” 7 (2020) nr 4, DOI: https:// doi.org/10.26451/abc. 
Stan naszej planety, Wypowiedź Sekretarza Generalnego ONZ na Uniwersytecie Columbia, 2 grudnia 2020 r., https://www.unic.un.org.pl/oionz/stan-naszej-planety/339o (9.05.2021).

The Human-Animal Boundary. Exploring the line in Philosophy and Fiction, red. N. Batra, M. Wenning, Leksington Books, Lanhan Boulder, New York 1978.

Warsztat Maxim, oficjalny film z Zgromadzenia NOW, («Мастерская Максим» официальное видео Ассамблеи NOW на YouTube), https:/www.youtube.com/ (9.05.2021).

Winter A., All about dolphinS! A multilingual educational manual, Produced by UNEP/ CMS Convention on Migratory Species and TUI, United Nations Premises in Bonn, 2007.

Пикник на обочине (Аркадий и Борис Стругацкие), Piknik przydrożny (Arkady i Borys Strugacki), 2006.

\section{Abstrakt}

\section{Człowiek w relacji do innych istot na Ziemi. Trendy współczesne}

Filozofowie, ekolodzy i behawioraliści domagają się poparcia dla Deklaracji praw waleni. Uważają, że delfiny i wieloryby są wystarczająco inteligentne, aby uzasadniać stosowanie wobec nich tych samych zasad etycznych co wobec ludzi. Wniosek oparty jest na wieloletnich badaniach, które wykazały, że delfiny i wieloryby mają duże i złożone mózgi, a także samoświadomość zbliżoną do poziomu ludzkiego. Deklaracja o prawach i wolności delfinów i wielorybów została zaprezentowana na corocznym spotkaniu American Association for the Advancement of Science, które odbyło się w kanadyjskim mieście Vancouver. To największa konferencja naukowa na świecie. Trwa akcja zbierania podpisów poparcia dla tej inicjatywy.

Eksperci uważają, że delfiny i wieloryby, niebędące istotami ludzkimi, są „, osobami" w filozoficznym tego słowa znaczeniu, a to już samo w sobie każe poważnie zastanowić się nad stosunkiem do nich. Profesor etyki Tom White z Loyola Marymount University w Los Angeles, autor książki In Defense of Dolphins: A New Moral Frontier, uważa, że delfiny nie są ludźmi, ale są osobami. Jego zdaniem nauka pokazała, że indywidualność i samoświadomość nie są już cechami właściwymi wyłącznie człowiekowi. A pociąga za sobą różne konsekwencje. Deklaracja, która została pierwotnie uzgodniona w maju 2010 roku, zawiera między innymi 
następujące postulaty: „zwierzęta z rodziny waleni nie mogą być trzymane w niewoli i eksploatowane, być poddawane okrucieństwu, pozbawiane swojego środowiska naturalnego”; „nie są one własnością żadnego państwa, korporacji, grupy ludzi czy jednostki”. W dokumencie stwierdza się również, że „prawa, wolności i normy określone w tej deklaracji muszą być chronione zgodnie z prawem międzynarodowym i krajowym". Laurie Marino z Emory University w Atlancie wyjaśnia, w jaki sposób postęp naukowy pomógł zmienić nasz sposób myślenia o mózgu waleni. Według niej mózg delfinów i wielorybów był początkowo przedstawiany naukowcom jako ogromna amorficzna masa, która nie posiadała znaczącej inteligencji i złożoności. Okazało się, że ich mózgi są nie tylko ogromne, ale także niesamowicie złożone, a ich złożoność jest porównywalna z naszymi mózgami. Delfiny mają poczucie swojej tożsamości, potrafią rozpoznać siebie w lustrze. Ewolucja gatunku i siedliska w naturalny sposób doprowadziły do wyjątkowej kombinacji świadomych cech delfinów. Są to niewątpliwie zwierzęta o złożonej organizacji, a natura ich inteligentnego zachowania niewiele różni się od naczelnych, słoni i krukowatych. Z punktu widzenia nauki ustalenie, które zwierzę jest osobą, a które nie, okazuje się filozoficznym ćwiczeniem.

Indie są krajem, w którym od dawna istnieje koncepcja osobowości nie-ludzkich. W XXI wieku w niektórych krajach zwierzęta zaczęły otrzymywać podstawowe prawa. W 2008 roku parlament Hiszpanii poparł pomysł przyznania takiego statusu małpom człekokształtnym, a Szwajcaria przyjęła bezprecedensową ustawę o prawach zwierząt. Etyczny stosunek do przyrody staje się ważnym krokiem w rozwoju cywilizacyjnym. I nie chodzi tu jedynie o zwierzęta, ale o samych ludzi. Rozpoznając osobowości delfinów, nie tylko przezwyciężamy oczywiste ludzkie okrucieństwo, ale także wychodzimy poza antropocentryczne postrzeganie świata. Jeśli marzymy o tym, by kiedyś stać się cywilizacją pozaplanetarną, gotową do komunikowania się z Wszechświatem, musimy zrozumieć, jak ewoluuje świadomość w różnych warunkach fizycznych. Powinniśmy również nauczyć się kontaktować z tymi, którzy żyją z nami na Ziemi.

Słowa kluczowe

deklaracja praw waleni, etyka, istoty inteligentne, ekologia 
